\title{
Pengaruh Tarif Pelayanan Terhadap Kinerja Keuangan Pada Badan Layanan Umum RSUP Dr. Wahidin Sudirohusodo Makassar
}

\author{
Fatmawati $^{1}$, Abdul Rahman Mus ${ }^{2} \&$ Ibrahim Dani $^{3}$ \\ 12,3, Magister Manajemen, Universitas Muslim Indonesia. \\ ${ }^{1}$ Koresponden Penulis, E-mail: fatmawati060480@gmail.com
}

\begin{abstract}
ABSTRAK
Penelitian ini bertujuan untuk mencari bukti empirik apakah penerapan Tarif Menkes RI, Tarif Otonomi Daerah dan Tarif BPJS Berpengaruh terhadap Kinerja keuangan RSUP.Dr.Wahidin Sudirohusodo Makassar, untuk melihat pengaruh penerapan Tarif Pelayanan terhadap Kinerja Keuangan Badan Layanan Umum RSUP.Dr.Wahidin Sudirohusodo Makassar menggunakan tiga variabel yaitu, Tarif Menkes (X1), Tarif otonomi Direksi (X2), dan Tarif BPJS (X3). Dalam penelitian ini, sampel yang diambil adalah 50 orang dari pasien yang berkunjung dan pegawai di RSUP. Dr. Wahidin Sudirohusodo Makassar. Pengumpulan data dilakukan melalui observasi langsung dan survei yang diperoleh dengan cara pembagian kuesioner kepada para responden. Penelitian ini menggunakan model analisis regresi linier berganda dengan software SPSS V 20.. Hasil penelitian menunjukkan bahwa Tarif otonomi Direksi dan Tarif BPJS berpengaruh positif dan signifikan terhadap kinerja keuangan Badan Layanan Umum RSUP. Dr. Wahidin Sudirohusodo Makassar dan Tarif Menkes RI berpengaruh positif dan tidak signifikan terhadap Kinerja Keuangan Badan Layanan Umum RSUP. Dr. Wahidin Sudirohusodo Makassar. Hal ini ditunjukkan dari hasil uji regresi linear berganda yang menunjukkan $Y=1,319+0,063 X 1+0,183 X 2+$ 0,503X3 . Berdasarkan hasil kesimpulan penelitian ini Penerapan Tarif Menkes RI,Tarif otonomi Direksi dan Tarif BPJS berpengaruh positif terhadap Kinerja Keuangan Badan Layanan Umum RSUP. Dr. Wahidin Sudirohusodo Makassar.
\end{abstract}

Kata Kunci: Tarif Pelayanan; Tarif Ekonomi; Kinerja keuangan

\begin{abstract}
This research aims to find empirical evidence whether the application of the Menkes tariff, regional autonomy tariff and BPJS tariff affect the financial performance of RSUP. Dr. Wahidin Sudirohusodo Makassar, to see the influence of the implementation of service tariffs on the financial performance of the RSUP public Services Agency. Dr. Wahidin Sudirohusodo Makassar uses three variables, namely Menkes Tariff (X1), the autonomy rate of the Board of Directors (X2), and the Tariff BPJS (X3). In this study, samples were 50 people from visiting patients and employees at RSUP. Dr. Wahidin Sudirohusodo Makassar. Data collection is conducted through direct observation and surveys obtained by the distribution of questionnaires to respondents. This research uses multiple linear regression analysis models with SPSS $V 20$ software. The results showed that the autonomous tariff of directors and tariffs of BPJS have a positive and significant effect on the financial performance of the RSUP General Services Agency. Dr. Wahidin Sudirohusodo Makassar and tariff Menkes RI effect positive and insignificant to the financial performance of public service agency RSUP. Dr. Wahidin Sudirohusodo Makassar. It is shown from a double linear regression test result showing $Y=1.319+0.063 X 1+0.183 X 2+0,503 X 3$. Based on the results of the conclusion of this research implementation of tariff Menkes RI, the tariff and tariff autonomy of BPJS has a positive effect on the financial performance of public service agency RSUP. Dr. Wahidin Sudirohusodo Makassar.
\end{abstract}

Keywords: Service Rates; Economic Rates; Financial performance 
Pengaruh Tarif Pelayanan, ... (Fatmawati, Mus \& Dani) | 116

\section{PENDAHULUAN}

Terwujudnya derajat kesehatan yang optimal sangat dipengaruhi oleh tersedianya layanan kesehatan yang dapat dijangkau oleh seluruh lapisan masyarakat. Untuk itu, diusahakan adanya pelayanan kesehatan yang lebih luas, lebih merata dan terjangkau, utamanya oleh masyarakat yang berpenghasilan rendah (Ferdinandus, 2014). Di lain pihak, tuntutan masyarakat baik secara kualitatif maupun kuantitatif terhadap pelayanan kesehatan makin meningkat. Rumah sakit yang merupakan salah satu fasilitas pelayanan kesehatan masyarakat, dalam menjalankan fungsi dan tanggung jawabnya sering diperhadapkan pada masalah tuntutan kualitas pelayanan oleh masyarakat, di sisi lain menghadapi problem investasi dan pengembangan rumah sakit (Tumbel, 2020). Problem ini terjadi karena daya subsidi pemerintah makin berkurang, sehingga subsidi yang terus menerus tidaklah dapat diandalkan untuk menutupi biaya yang diperlukan dalam memproduksi jasa pelayanan rumah sakit.

Pengertian dan fungsi manajemen keuangan adalah menyangkut kegiatan perencanaan, analisis dan pengendalian kegiatan keuangan (Dunia \& Abdullah, 2012). RSUP Dr. Wahidin Sudirohusodo Rumah Sakit adalah merupakan salah satu unit pelayanan kesehatan masyarakat yang utama, sehingga dalam menjalankan fungsi dan tanggung jawabnya diperhadapkan pada masalah yang sangat mendasar yaitu tuntutan masyarakat akan pelayanan berkualitas yang tidak semata diberikan oleh tenaga medis dan keperawatan tetapi menyangkut seluruh aspek yang terkait dengan pelayanan kepada pasien terutama tarif setiap jenis pelayanan atau tindakan yang diberikan (Pujilestari, Maidin, \& Anggraeni, 2016). Badan Layanan Umum Rumah Sakit Umum Pusat Dr. Wahidin Sudirohusodo Makassar adalah salah satu Unit Pelaksana Teknis Departemen Kesehatan Republik Indonesia yang bertanggungjawab menyelenggarakan pembangunan kesehatan, merupakan pusat pelayanan kesehatan terdepan yang mempunyai posisi yang sangat strategis dalam mewujudkan Visi Indonesia 2015 (Nurelisa, 2016).

Manajemen keuangan adalah segala aktivitas yang berhubungan dengan perolehan dana dan pengelolaan aktiva dengan beberapa tujuan menyeluruh. Dengan demikian fungsi pembuatan keputusan dari manajemen keuangan dapat dibagi tiga kelompok utama yaitu keputusan yang berhubungan dengan investasi, pendanaan dana manajemen aktiva (Nurhayati, 2017). Berdasarkan distribusi dari sarana pelayanan kesehatan, Rumah Sakit dapat dikatakan telah merata keberadaannya pada seluruh pelosok wilayah, namun harus diakui bahwa distribusi sarana pelayanan tersebut belum sepenuhnya diikuti dengan peningkatan mutu pelayanan dan keterjangkauan oleh seluruh lapisan masyarakat (Aspari, 2014).

Memenuhi dan memfasilitasi segala kebutuhan pelayanan kepada pasien/pelanggan telah mengakibatkan pembiayaan pelayanan kesehatan dari tahun ke tahun di satu sisi mengalami peningkatan yang cukup tajam, sedangkan pada sisi lain subsidi dari Pemerintah pusat sangat terbatas. Untuk itu, paradigma terhadap pengelolaan Rumah Sakit dewasa ini harus berorientasi bisnis tanpa mengesampingkan fungsi sosial ekonomi dalam memberikan pelayanan kesehatan masyarakat (Hartanto, 2009). Berdasarkan Surat Keputusan Menteri Kesehatan Republik Indonesia Nomor: 540/SK/VI/1994 Rumah Sakit Dr. Wahidin Sudirohusodo Makassar ditetapkan 
sebagai Rumah Sakit Pendidikan Tipe A dan juga sekaligus sebagai pusat rujukan tertinggi di Kawasan Timur Indonesia (KTI) (Hijriahni, 2019).

Kemudian dengan diterbitkannya Peraturan Pemerintah Nomor: 125 Tahun 2000, Rumah Sakit Dr. Wahidin Sudirohusodo Makassar berubah statusnya menjadi Perusahaan Jawatan (Perjan) yang berlaku secara efektif mulai tanggal 01 Januari 2002. Sejalan dengan perkembangan dunia usaha dalam sektor publik, khususnya Rumah Sakit dewasa ini, berdasarkan Peraturan Pemerintah Nomor: 23 Tahun 2005 dan Peraturan Menteri Keuangan Nomor: 07/PMK.02/2006 tentang Pengelolaan Keuangan Badan Layanan Umum, maka Rumah Sakit Dr. Wahidin Sudirohusodo Makassar berubah statusnya menjadi Badan Layanan Umum (BLU) dan berlaku mulai 1 Januari 2006. Badan Layanan Umum Rumah Sakit Umum Pusat Dr. Wahidin Sudirohusodo Makassar dalam upaya memberikan pelayanan yang terbaik bagi masyarakat di Kota Makassar, diperlukan dana yang besar. Sedangkan subsidi dari Pemerintah sangat terbatas, maka pihak manajemen Rumah Sakit menerapkan kebijakan tarif pelayanan. Tarif pelayanan yang diterapkan berupa tarif yang sesuai dengan Menteri Kesehatan Republik Indonesia, tarif otonomi direksi, tarif BPJS, dan tarif Jamkesmas.

Tarif-tarif ini merupakan suatu bentuk solusi yang diterapkan oleh Rumah Sakit dalam memberikan pelayanan berdasarkan pengenaan tarif jenis rawat inap dan rawat jalan. Gambaran operasional yang dapat dilihat saat ini bahwa tarif Menteri Kesehatan Republik Indonesia diperuntukkan hanya untuk rawat inap kelas III. Tarif otonomi Direksi diperuntukkan untuk rawat inap dan rawat jalan. Rawat inap bentuk VIP, kelas I dan Kelas II. Sedangkan tarif BPJS rawat jalan dan rawat inap diperuntukkan untuk kelas I, Kelas II, dan III. Tarif Jamkesmas diperuntukkan rawat jalan dan rawat inap kelas III. Tarif Jamkesda diperuntukkan untuk rawat jalan dan rawat inap kelas III.

Sebagai Rumah Sakit kelas A yang digunakan sebagai tempat pendidikan dan penelitian serta berfungsi sebagai pusat rujukan kawasan Timur Indonesia, Badan Layanan Umum Rumah Sakit Umum Pusat Dr. Wahidin Sudirohusodo Makassar memiliki Sumber Daya Manusia profesional yang didukung sarana, prasarana dan peralatan yang memadai sehingga memiliki kemampuan untuk memberikan pelayanan medis spesialistik luas. Kinerja perusahaan adalah hasil dari banyak keputusan individual yang dibuat secara terus menerus oleh manajemen (Rani, Basalamah \& Damis, 2020). Oleh karena itu, untuk menilai kinerja perusahaan ini perlu dilibatkan analisis dampak keuangan komulatif dan ekonomi dari keputusan, serta mempertimbangkannya dengan ukuran komparatif.

Berkaitan dengan pernyataan tersebut, ditambahkan bahwa analisis kinerja perusahaan harus berdasarkan data keuangan yang dipublikasikan pada laporan keuangan yang dibuat sesuai dengan prinsip akuntansi yang lazim. Dimana laporan ini merupakan data yang paling umum tersedia untuk tujuan tersebut, walaupun seringkali tidak mewakili hasil dari kondisi ekonomi, karena laporan keuangan adalah kartu yang memuat hasil investasi, operasi dan pembiayaan perusahaan. Tarif menurut (Mulyadi, 2002) adalah suatu harga produk/jasa sebagai interaksi antar jumlah demand dan supply di pasar. Mulyadi (1997) mengemukakan bahwa 
dalam keadaan normal harga atau tarif harus menutup biaya penuh (full cost) yang terkait dengan produk dan menghasilkan laba yang dikehendaki.

Tarif adalah harga komponen atau kegiatan yang dibebankan kepada masyarakat sebagai imbalan atas pelayanan yang diterima dari rumah sakit (SK Menkes no. 282, 1993). Perhitungan tarif merupakan kegiatan setelah diperoleh informasi biaya satuan rumah sakit. Informasi biaya satuan adalah informasi yang menggambarkan besarnya biaya pelayanan bagi tiap pasien dan dapat digunakan untuk penetapan tarif bagi rumah sakit. Dengan diketahuinya biaya satuan maka dapat diketahui apakah tarif yang ada sekarang merugi, tetap atau menguntungkan dan juga dapat diketahui berapa besar rumah sakit dapat menutupi biaya yang telah dikeluarkan.

Tarif adalah salah satu penerimaan dari Rumah Sakit selain dari: hibah, hasil kerja sama dengan pihak lain, APBD, APBN, hasil investasi, dan lain-lain. Tarif merupakan sebagian atau seluruh biaya penyelenggaraan kegiatan pelayanan medik dan non medik yang dibebankan kepada masyarakat sebagai imbalan atas jasa pelayanan yang diterimanya. Dimana pengenaan tarif Rumah Sakit ini tidak dimaksudkan untuk mecari laba dan ditetapkan dengan asas gotong royong dan adil dengan mengutamakan kepentingan masyarakat yang berpenghasilan rendah atau masyarakat miskin. Adapun dasar pengenaan tarif Rumah Sakit ditetapkan atas dasar jenis pelayanan, klasifikasi Rumah Sakit, tingkat kecanggihan pelayanan dan kelas perawatan. Tarif Rumah Sakit merupakan aspek yang sangat diperhatikan oleh Rumah Sakit Pemerintah. Bagi sebagian Rumah Sakit Pemerintah, tarif memang ditetapkan berdasarkan Surat Keputusan Menteri Kesehatan atau Pemerintah Daerah. Hal ini menunjukkan adanya kontrol ketat Pemerintah sebagai pemilik terhadap Rumah Sakit sebagai firma atau pelaku usaha. Akan tetapi disadari bahwa tarif Pemerintah pada umumnya mempunyai cost - recovery (pemulihan biaya) yang rendah. Apabila tarif mempunyai tingkat pemulihan biaya diberlakukan pada kelas layanan bawah (misalnya kelas III) maka hal tersebut merupakan sesuatu yang layak, sehingga terjadi subsidi Pemerintah bagi masyarakt miskin untuk menggunakan pelayanan Rumah Sakit. Akan tetapi, apabila tingkat pemulihan biaya ternyata juga rendah untuk kelas VIP misalnya, maka dapat terjadi subsidi untuk masyarakat atas.

Menurut Mulyadi (2012), dalam arti luas biaya adalah pengorbanan sumber ekonomis, yang diukur dalam satuan uang yang terjadi atau yang kemungkinan akan terjadi untuk mencapai tujuan tertentu. Pada dasarnya tarif bukan hanya harga yang harus dibayar, tetapi harus dapat menggambarkan adanya pedoman yang disebut dengan kebijakan tarif merupakan dasar pemikiran tarif. Jenis kebijakan itu antara lain cost based princing yaitu penentuan tarif dasar biaya yang dikeluarkan. Demand based princing yaitu penentuan tarif dasar permintaan biaya yang dikeluarkan (Marhono, 2020). Pendapatan merupakan kenaikan kotor atau garis dalam modal pemilik yang dihasilkan dari penjualan barang dagangan, pelayanan jasa kepada klien, penyewaan harta, peminjaman uang dan semua kegiatan yang bertujuan untuk memperoleh penghasilan (Nariswari, Zaenuddin, \& Lubis, 2016). Pendapatan adalah hasil penjualan barang dan jasa yang di bebankan kepada langganan/mereka yang menerima (Damayanti, 2016). 


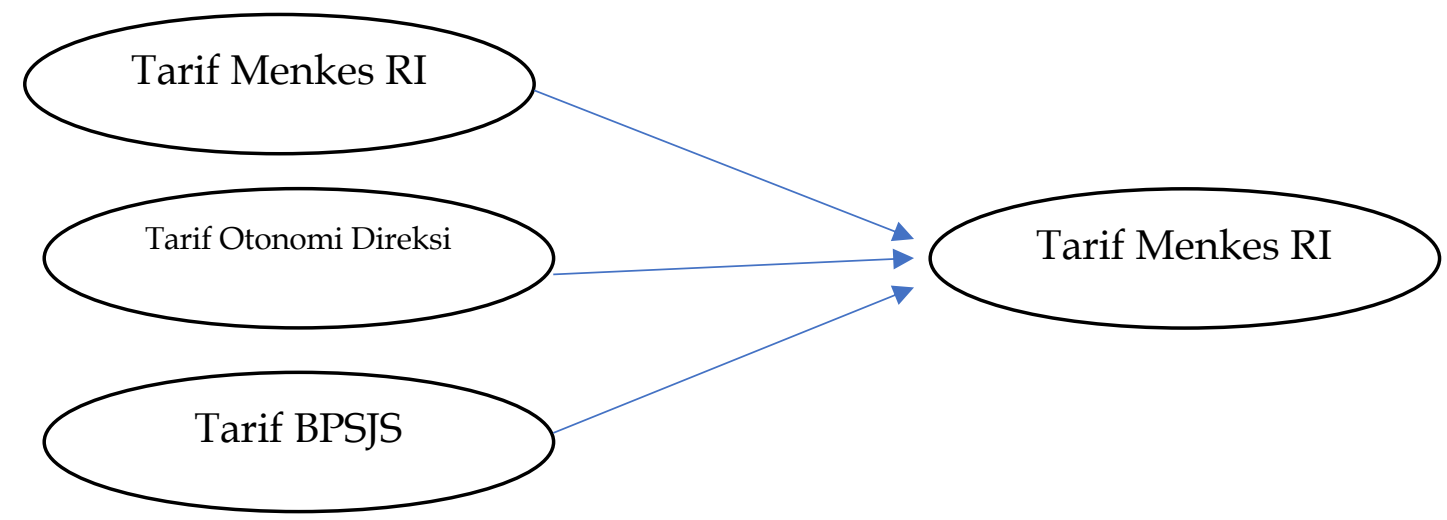

Berdasarkan rumusan masalah dan uraian-uraian di atas, maka hipotesis yang diajukan dalam penelitian ini dari teori diatas adalah:

1. Tarif Menkes RI, Tarif Otonomi Direksi dan Tarif BPJS secara parsial mempunyai pengaruh signifikan terhadap Kinerja Keuangan pada Badan Layanan Umum RSUP. Dr. Wahidin Sudirohusodo Makassar

2. Bahwa dari ketiga variabel yaitu Tarif Menkes RI, Tarif Otonomi Direksi dan Tarif BPJS yang paling dominan berpengaruh terhadap Kinerja Keuangan pada badan layanan Umum RSUP. Dr. Wahidin Sudirohusodo Makassar adalah Tarif BPJS.

\section{METODE PENELITIAN}

Penelitian dirancang sebagai penelitian kausal dengan pendekatan kuantitatif. Penelitian kausal berguna untuk mengukur hubungan antara variabel riset, atau untuk menganalisis bagaimana pengaruh suatu variabel terhadap variabel lainnya (Umar 2003;28). Peneliti menggunakan desain penelitian ini untuk mengetahui apakah penerapan Tarif Menkes RI, Tarif Otonomi Direksi dan Tarif BPJS. Penelitian yang dilaksanakan di RSUP. Dr. Wahidin Sudirohusodo Makassar. Karna jumalh sampel yang sangat sedikit maka pengambilan sampel menggunakan sampel jenuh yaitu seluru pegawai di ada di RSUP Dr. Wahidin Sudirohusodo sebanyak 50 orang, metode analisi penelitian ini Analisis deskriptif ini merupakan analisis yang mengemukakan tentang data diri responden, yang diperoleh dari jawaban responden melalui kuisioner. Dengan uji validas, reliabilitas dan analisis regresi linier berganda.

\section{HASIL PENELITIAN DAN PEMBAHASAN}

\section{Hasil}

Uji regresi linear berganda untuk mengetahui ada tidaknya pengaruh variabel independen terhadap variabel dependen. Besarnya pengaruh variabel independen terhadap variabel dependen secara bersama-sama dapat dihitung melalui suatu persamaan regresi berganda 
Tabel 1.

\begin{tabular}{|c|c|c|c|}
\hline & \multirow[b]{2}{*}{ Model } & \multicolumn{2}{|c|}{ Unstandardized Coefficients } \\
\hline & & B & Std. Error \\
\hline \multirow{4}{*}{1} & (Constant) & 1.319 & 498 \\
\hline & $\mathrm{X} 1$ & .063 & .107 \\
\hline & $\mathrm{X} 2$ & .183 & .084 \\
\hline & X3 & .503 & .097 \\
\hline
\end{tabular}

a. Dependent Variable: $\mathrm{Y}$

Dari tabel diatas dapat diperoleh rumus regresi sebagai berikut:

$$
Y=1,319+0,063 \times 1+0,183 \times 2+0,503 X 3
$$

Dalam persamaan regresi diatas dapat di lihat bahwa, konstanta $(\beta 0)$ adalah sebesar 1,319 hal ini berarti jika tidak ada perubahan variabel pada Tarif Menkes RI (X1), Tarif Otonomi Daerah (X2) dan Tarif BPJS(X3), yang mempengaruhi, maka Kinerja Keuangan instansi pemerintah yang terjadi pada RSUP. Dr. Wahidin Sudirohusodo Makassar sebesar 1,319. Sedangkan hasil uji regresi berganda untuk variabel independen dapat dijelaskan sebagai berikut:

1. Nilai koefisien Tarif Menkes RI (X1) sebesar 0,063 berpengaruh positif terhadap Kinerja Keuangan Pada Badan Layanan Umum RSUP. Dr. Wahidin Sudirohusodo Makasar (Y). Hal ini mengandung arti bahwa setiap kenaikan Tarif Menkes satu satuan maka variabel Kinerja Keuangan instansi RSUP. Dr. Wahidin Sudirohusodo Makassar naik sebesar 0,063 dengan asumsi bahwa variabel independen yang lainnya tetap.

2. Nilai koefisien Tarif Otonomi Direksi (X2) sebesar 0,183 berpengaruh positif terhadap Kinerja Keuangan Pada Badan Layanan Umum RSUP. Dr. Wahidin Sudirohusodo Makasar (Y). Hal ini mengandung arti bahwa setiap kenaikan Tarif Otonomi Direksi satu satuan maka variabel Kinerja Keuangan Pada Badan Layanan Umum RSUP. Dr. Wahidin Sudirohusodo Makasar naik sebesar 0,183 dengan asumsi bahwa variabel independen yang lainnya tetap.

3. Nilai koefisien Tarif BPJS (X3) sebesar 0,503 berpengaruh positif terhadap Kinerja Keuangan Pada Badan Layanan Umum RSUP. Dr. Wahidin Sudirohusodo Makasar (Y). Hal ini mengandung arti bahwa setiap kenaikan tarif BPJS satu satuan maka variabel Kinerja Keuangan Pada Badan Layanan Umum RSUP. Dr. Wahidin Sudirohusodo Makasar naik sebesar 0,503 dengan asumsi bahwa variabel independen yang lainnya tetap.

Analisis koefisien determinasi dilakukan untuk melihat seberapa besar presentase pengaruh variabel Tarif Menkes RI, Tarif otonomi Direksi, Tarif BPJS, terhadap Kinerja Keuangan pada Badan Layanan Umum RSUP. Dr. Wahidin Sudirohusodo Makassar 
Tabel 2

Koefisien Determinasi

\begin{tabular}{ccccc}
\multicolumn{5}{c}{ Model Summary } \\
\hline Model & $\mathrm{R}$ & $\mathrm{R}$ & $\begin{array}{c}\text { Adjusted R } \\
\text { Square }\end{array}$ & $\begin{array}{c}\text { Std. Error of } \\
\text { the Estimate }\end{array}$ \\
\hline 1 & $.696^{\mathrm{a}}$ & .593 & .451 & .31406 \\
\hline
\end{tabular}

a. Predictors: (Constant), X1, X2, X3,

Berdasarkan tabel diatas, menunjukkan bahwa nilai $\mathrm{R}$ square yang diperoleh sebesar 0,593 yang menunjukan bahwa kinerja keuangan yang ada pada RSUP. Dr. Wahidin Sudirohusodo Makassar dipengaruhi oleh tiga variabel yaitu tarif menkes RI, tariff otonomi Direksi, dan tarif BPJS sebesar 59,3\%, dan sisanya 40,7\% dipengaruhi oleh variabel lain yang belum diteliti dalam penelitian ini. Dengan melihat nilai koefisien yang tinggi menunjukkan pengaruh variable-variabel independen terhadap variabel dependen yang juga tinggi yaitu sebesar 59,3\%.

Pengujian ini dilakukan untuk menguji apakah terdapat pengaruh yang signifikan antara tarif Menkes RI, tarif otonomi direksi, dan Tarif BPJS terhadap Kinerja Keuangan Badan Layanan Umum RSUP. Dr. Wahidin Sudirohusodo Makassar secara bersama - sama.

Tabel 3

Hasil Pengujian Simultan (uji F)

ANOVA $^{b}$

\begin{tabular}{ccccccc}
\hline \multicolumn{2}{c}{ Model } & $\begin{array}{c}\text { Sum of } \\
\text { Squares }\end{array}$ & Df & $\begin{array}{c}\text { Mean } \\
\text { Square }\end{array}$ & F & Sig. \\
\hline \multirow{2}{*}{1} & Regression & 4.274 & 3 & 1,425 & 14.444 & $.000^{\mathrm{a}}$ \\
& Residual & 4.537 & 46 & .099 & & \\
& Total & 8.811 & 49 & & & \\
\hline
\end{tabular}

a. Predictors: (Constant), X4, X1, X2

b. Dependent Variable: $Y$

Berdasarkan tabel di atas, menunjukkan nilai signifikansi $F$ sebesar 0.000 berdasarkan kriteria pengujian bahwa jika nilai probabilitas $<0,05$, maka $\mathrm{H} 1$ diterima. Sehingga dapat disimpulkan dari tabel di atas bahwa secara serempak tarif Menkes RI, tarif otonomi direksi, dan Tarif BPJS berpengaruh signifikan terhadap Kinerja Keuangan Badan Layanan Umum RSUP. Dr. Wahidin Sudirohusodo Makassar. Hal ini ditunjukkan dari nilai signifikan $F=0.000<0,05$. Sehingga jika tarif Menkes RI, tarif otonomi direksi, dan Tarif BPJS secara bersama-sama meningkat, maka Kinerja keuangan badan layanan umum RSUP. Dr. Wahidin Sudirohusodo Makassar juga akan meningkat.

Pengujian secara parsial (uji t) dilakukan untuk menentukan apakah variabel tarif Menkes RI, tarif otonomi direksi, dan Tarif BPJS berpengaruh terhadap efektivitas kinerja instansi RSUP. Dr. Wahidin 
Tabel 4

Hasil Pengujian Parsial (Uji t) Sudirohusodo Makassar secara parsial.

\begin{tabular}{|c|c|c|c|c|c|c|}
\hline & \multirow[t]{2}{*}{ Model } & \multicolumn{2}{|c|}{$\begin{array}{l}\text { Unstandardized } \\
\text { Coefficients }\end{array}$} & \multirow{2}{*}{$\begin{array}{c}\begin{array}{c}\text { Standardize } \\
\text { d } \\
\text { Coefficients }\end{array} \\
\text { Beta }\end{array}$} & \multirow[t]{2}{*}{$\mathrm{T}$} & \multirow[t]{2}{*}{ Sig. } \\
\hline & & B & Std. Error & & & \\
\hline \multirow[t]{4}{*}{1} & (Constant) & 1.319 & .498 & & 2.649 & .011 \\
\hline & $\mathrm{X} 1$ & .063 & .107 & .063 & .591 & .558 \\
\hline & $\mathrm{X} 2$ & .183 & .084 & .244 & .2 .176 & .035 \\
\hline & $\mathrm{X} 3$ & .503 & .097 & .574 & 5.170 & .000 \\
\hline
\end{tabular}

a. Dependent Variable: $Y$

Dari tabel di atas menunjukkan hasil uji $t$ adalah:

1. Tarif Menkes RI berpengaruh positif dan tidak signifikan terhadap kinerja keuangan badan layanan umum RSUP. Dr. Wahidin Sudirohusodo Makassar secara parsial hal ini dibuktikan dengan tingkat signifikansi $>0,05$ dan hipotesis Ha1 ditolak

2. Tarif otonomi direksi berpengaruh positif dan signifikan terhadap kinerja keuangan badan layanan umum RSUP. Dr. Wahidin Sudirohusodo Makassar secara parsial. Hal ini dibuktikan dengan tingkat signifikansi yang diperoleh < 0,05

3. Tarif BPJS berpengaruh positif dan signifikan terhadap kinerja keuangan badan layanan umum RSUP. Dr. Wahidin Sudirohusodo Makassar secara parsial hal ini dibuktikan dengan tingkat signifikansi < 0,05 dan hipotesis Ha2 diterima, dengan melihat hasil dari ke tiganya, maka tariff BPJS yang paling dominan terhadap Kinerja Keuangan RSUP. Dr. Wahidin Sudirohusodo Makassar.

\section{Pembahasan}

1. Hasil Uji Pengaruh Tarif Menkes RI (X1) Terhadap kinerja Keuangan Badan Layanan Umum RSUP. Dr. Wahidin Sudirohusodo Makassar (Y)Untuk nilai Pengaruh Kompensasi Terhadap Kinerja

Tarif Menkes terdiri dari dua jenis tarif yaitu tarif rawat jalan dan tarif rawat inap, dimana tarif ini setiap tahunnya mengalami perubahan sesuai dengan penetapan Ketentuan Menteri kesehatan dalam penetapan tarifnya. Dimana tahun 2018 PMK nomor 51 mengenai penetapan tarif rawat inapnya jauh berbeda nilainya dengan Permenkes Nomor 16 tahun 2019 dalam hal tarif rawat inap, hal ini disebabkan karena biaya pengunaan bahan meliputi alkes pakai habis farmasi, bahan gizi, linen dan biaya langsung lainnya. setiap bahan tersebut di pengaruhi oleh harga belinya. sedangkan untuk tarif pada rawat jalan mempunyai elemen bahan pakai habis yang cukup rendah. dan berdasarkan hasil uji parsial yang telah dilakukan antara tarif Menkes RI sebagai X1 terhadap Kinerja Keuangan RSUP. Dr. Wahidin Sudirohusodo Makassar sebagai variabel Y menunjukkan bahwa t hitung sebesar 0.591 dengan nilai signifikansi sebesar 0,558 > 0,05 dan hasil uji regresi berganda menunjukkan nilai 
koefisien sebesar 0,063 menunjukkan bahwa variabel Tarif Menkes berpengaruh positif dan tidak signifikan terhadap Kinerja keuangan RSUP. Dr. Wahidin Sudirohusodo Makassar

Dengan demikian dapat disimpulkan bahwa ketika tarif menkes tidak sesuai dengan pengaturan perencanaan dan perhitungan untuk menentukan besaran tarif Rumah Sakit yang di tetapkan maka kinerja keuangan pada badan layanan umum RSUP. Dr. Wahidin Sudirohusodo Makassar juga tidak signifikan. Sehingga untuk meningkatkan kinerja keuangan perlu dilakukakan perencanaan biaya satuan (unit cost) yang baik karena perencanaan merupakan pondasi dalam menentukan keberhasilan atau kegagalan dalam sebuah organisasi atau instansi. Selain itu Pemerintah dalam hal perencanaan tarif yang dbuat sebaiknya merangkum sedetil mungkin apa saja kekurangan yang ada pada manajemen tiap satuan kerja Rumah sakit dalam kegiatan yang dilakukan serta kontrol mekanisme praktek kerja Rumah sakit. Hasil penelitian ini sejalan dengan penelitian yang dilakukan oleh syahridar (2010) dengan judul Pengaruh Tarif Menkes dan Tarif Otonomi Direksi Terhadap efektivitas Kinerja Instansi RSUP. Dr. Cipto Mangunkusumo Jakarta Pusat. Hasil penelitiannya menunjukkan bahwa Perencanaan tarif menkes berpengaruh positif dan tidak signifikan terhadap efektivitas Kinerja Instansi Rumah Sakit daerah

Nilai koefisien sebesar 0,184 dengan tanda positif yang berarti dengan pemberian kompensasi berupa bonus ataupun penghragaan berpengaruh positif terhadap kinerja atau dapat diartikan pula setiap pemberian kompensasi akan meningkatkan kinerja pegawai itu sendiri. Hasil ini sejalan dengan teori yang di kemukakan oleh Handoko yang menjelaskan bahwa kommpensasi itu merupakan segala sesuatu yang diterima karyawan sebagai balas jasa atas kerja mereka. Pemberian kompensasi merupakan salah satu meningkatkan kerja mereka, motivasi dan kepuasan karyawan. Kompensasi tidak hanya berkaitan dengan imbalan-imbalan moneter saja, tetapi juga pada tujuan dan imbaan intrinsik organisasi seperti pengakuan maupun kesempatan promosi.

\section{Hasil Uji Pengaruh Tarif Otonomi Direksi Terhadap Kinerja Keuangan Badan Layanan Umum RSUP.Dr. Wahidin Sudirohusodo Makassar (Y)}

Tarif otonomi direksi adalah tarif yang ditetapkan atas dasar kebijakan pimpinan otonomi direksi dalam melihat bagaimana kebutuhan pengelolaan yang memberikan adanya tingkat keuntungan dan mengimbangi kebijakan-kebijakan penetapan tarif yang tidak sesuai dengan sosialisasi penetapan anggaran pembiayaan yang dikeluarkan dengan kepentingan yang diperoleh dari hasil pengelolaan, sehingga kebijakan direksi menjadi pertimbangan penetapan tarif. Berdasarkan hasil uji parsial yang telah dilakukan antara tarif Otonomi Direksi sebagai X2 terhadap Kinerja Keuangan BLU RSUP. Dr. Wahidin Sudirohusodo Makassar sebagai variabel Y menunjukkan bahwa t hitung sebesar 2,176 dengan nilai signifikansi sebesar 0,035 $<0,05$ dan hasil uji regresi berganda menunjukkan nilai koefisien sebesar 0,183 menunjukkan bahwa variabel tarif otonomi direksi berpengaruh positif dan signifikan terhadap kinerja keuangan badan layanan umum RSUP. Dr. Wahidin Sudirohusodo Makassar Dengan demikian dapat disimpulkan bahwa ketika tarif otonomi direksi yang diberlakukan kepada pasien atau masyarakat sesuai dengan kualitas pelayanan maka semakin besar pula Kinerja keuangan BLU RSUP. Dr. 
Wahidin Sudirohusodo Makassar, karena dalam hal ini tarif otonomi direksi memiliki kewenangan budget, ketika pemasukan rumah sakit naik, hal ini tentunya berdampak pada keuntungan yang di peroleh, seperti berdampak pada kenaikan insentif atau jasa medis dan non medis pegawai. Dalam menentukan tarif otonomi direksi dampaknya pada kinerja keuangan dalam artian penyusunan tarif yang memungkinkan terjadinya komunikasi dan koordinasi antar bagian yang lebih baik, sebagai contoh direktur Rumah Sakit mengkomunikasikan hasil laporan keuangan serta hasil dari tiap kegiatan yang ada terhadap para kepala bagian masing-masing, sehingga mereka tau apa yang diharapkan darinya dan alur keuangan apa yang berlaku terhadap kegiatan baik itu untuk dokter, perawat, dsb, dengan mengetahui alur keuangan yang berlaku terhadap kegiatannya, masing-masing bagian dapat membuat perencanaan tarif yang baik untuk pengambilan keputusan pada tarif otonomi direksi.

\section{Hasil Uji Pengaruh Tarif BPJS terhadap kinerja Keuangan Badan Layanan Umum RSUP.Dr. Wahidin Sudirohusodo Makassar (Y)}

Tarif BPJS merupakan tarif jaminan asuransi kesehatan yang dikenakan kepada masyarakat yang memiliki tanggungan jaminan kesehatan dari instansi atau perusahaan terdaftar menjadi anggota BPJS, Penetapan Tarif BPJS diberlakukan untuk kelas 1, 2 dan 3 dan untuk kenaikan kelas diberlakukan hanya naik 1 tingkat dari hak kelas yang dimiliki, serta Variasi tarif INA-CBG's antar kelas rumah sakit yang sangat lebar, serta variasi tarif antar kelas kamar pelayanan yang membedakan komponen biaya medis. Berdasarkan hasil uji parsial yang telah dilakukan antara Tarif BPJS sebagai X3 terhadap Kinerja Keuangan badan Layanan Umum RSUP. Dr. Wahidin Sudirohusodo Makassar sebagai variabel Y menunjukkan bahwa t hitung sebesar 5.170 dengan nilai signifikansi sebesar 0,000<0,05 dan hasil uji regresi berganda menunjukkan nilai koefisien sebesar 0,503 menunjukkan bahwa variabel Tarif BPJS berpengaruh positif dan signifikan terhadap Kinerja Keuangan Badan Layanan Umum RSUP. Dr. Wahidin Sudirohusodo Makassar dan merupakan variabel yang dominan diantara ketiga variabel lainnya. Dengan demikian dapat disimpulkan bahwa Tarif BPJS dapat mempengaruhi kinerja keuangan dengan adanya peningkatan pendapatan. Ketiga tarif tersebut menjadi pertimbangan dalam mengambil suatu kebijakan penetapan tarif yang diberlakukan. Secara parsial pada tarif yang paling berpengaruh karena kebijakan penetapan tarif adalah tarif BPJS dimana lebih kecil dibawah perhitungan tarif biaya unit Menkes maupun Tarif Otonomi direksi, itulah yang membuat masyarakat lebih banyak yang memanfaatkan tarif BPJS.

\section{Kinerja Keuangan Pada Badan Layanan Umum RSUP.Dr.Wahidin Sudirohusodo Makassar}

Pendapatan adalah keuntungan yang diperoleh dari aktifitas pengelolaan berdasarkan penetapan tarif yang diberlakukan terdiri dari tarif menkes RI, tarif otonomi direksi dan tarif BPJS. Penetapan tarif ini akan memberikan kontribusi terhadap tingkat pendapatan pengelolaan rumah sakit berdasarkan penggunaan biaya-biaya yang dikeluarkan dengan keuntungan hasil pengelolaan dan penggunaan jasa pemanfaatan fasilitas alat dan perlengkapan rumah sakit. Dalam hal ini pegawai melakukan analisis keuangan pada setiap kegiatan atau program 
yang selesai dilaksanakan, Kejelasan sasaran Tarif suatu Pelayanan harus dimengerti oleh semua karyawan, Membuat laporan kepada atasan setiap program yang telah dilaksanakan serta Laporan Keuangan Rumah Sakit digunakan sebagai bahan pertimbangan untuk merencanakan kegiatan dan dalam penetapan tarif yang akan diberlakukan nantinya. Dalam hal ini kinerja keuangan badan Layanan umum RSUP. Dr. Wahidin Sudirohusodo Makassar dilihat dari rasio likuiditasnya yaitu kemampuan RSUP. Dr. Wahidin Sudirohusodo mampu memenuhi kewajiban pada saat jatuh tempo dari perbandingan aset lancar berbanding utang lancar yang dapat dipenuhi sesuai ketentuan yang telah ditetapkan.kemudian rasio solvabilitas yaitu hasil keuntungan atau laba yang diperoleh dari hasil pengelolan kegiatan rumah sakit setelah dikurangi dengan biaya-biaya yang ada.dan yang terakhir adalah rasio aktivitas, yaitu Rumah sakit memanfaatkan seluruh sumber daya yang dimiliki secara efektif dan efisien.

\section{KESIMPULAN}

Kinerja keuangan pada RSUP. Dr. wahidin Sudirohusodo Makassar mengalami kenaikan dalam kegiatan pengelolaan Rumah Sakit, salah satu faktor yang menyebabkan adalah penetapan tiga jenis tarif yang berbeda oleh pihak masingmasing yang berwenang untuk di terapkan di rumah sakit dan Ketiga bentuk tarif pelayanan (tarif menteri kesehatan RI, tarif otonomi direksi, dan tarif BPJS) berdasarkan dari hasil pengujian bahwa ketika Penerapan Tarif Unit Naik, maka terhadap kinerja Keuangan RSUP. Dr. Wahidin Sudirohusodo Makassar juga naik demi pembiayaan Rumah Sakit yang semakin meningkat. Serta variabel tarif otonomi direksi dan tarif BPJS mempunyai pengaruh dominan terhadap peningkatan kinerja keuangan (pendapatan) secara parsial yang menjadi pertimbangan dalam mengambil suatu kebijakan pemberlakuan pengenaan tarif Adapun saran dalam penelitian ini Dalam penetapan tarif pelayanan harus di tinjau kembali agar tarif pelayanan yang berlaku dapat memberikan kontribusi bagi rumah sakit terhadap pembiayaan yang semakin meningkat. Dan Dalam implementasi atau pelaksanaan penetapan nilai tarif RSUP. Dr. Wahidin Sudirohusodo Makassar sebaiknya lebih memonitoring pelaksanaan program/kegiatan seberapa jauh pelaksanaannya dan memperbaiki sistem akuntansi keuangan dalam hal pencatatan penggunaan anggaran demi perencanaan penetapan tarif.

\section{DAFTAR PUSTAKA}

Apsari, R. A. (2014). Hubungan Kualitas Permukiman Dan Fasilitas Pelayanan Kesehatan Terhadap Derajat Kesehatan Masyarakat Berdasarkan Aplikasi Penginderaan Jauh Dan Sistem Informasi Geografi Daerah Kecamatan Pasar Kliwon (Doctoral dissertation, Universitas Muhammadiyah Surakarta).

Damayanti, E. F. (2016). Analisis Pengakuan Pendapatan pada Perusahaan Konstruksi. Akuisisi: Jurnal Akuntansi, 12(1).

Dunia, F. A., \& Abdullah, W. (2012). Akuntansi biaya. Jakarta: Salemba Empat. 
Ferdinandus, M. E. (2014). Pemberdayaan Puskesmas Menur Dalam Rangka Peningkatan Kualitas Pelayanan Publik Bidang Kesehatan 2 (Doctoral dissertation, UNIVERSITAS AIRLANGGA).

Hartanto, F. M. (2009). Paradigma baru manajemen Indonesia: menciptakan nilai dengan bertumpu pada kebajikan dan potensi insani. PT Mizan Publika.

Hijriahni, N. (2017). Analisis Tingkat Kelelahan Kerja Perawat di Ruang UGD RSP Universitas Hasanuddin dan RSUP DR. Wahidin Sudirohusodo Makassar (Doctoral dissertation, Universitas Islam Negeri Alauddin Makassar).

Margono, T. (2000). Aspek-aspek Biaya Dalam Jasa Informasi. Jurnal Akuntansi dan Keuangan, 2(2), 95-103.

Mulyadi.1993. Organisasi, Teori, Struktur, dan Proses. Jakarta.Depdikbud

Nariswari, E., Zaenuddin, M., \& Lubis, F. (2016). Perbandingan Completed Contract Method dan Percentage of Completion Method sebagai Alternatif Pilihan dalam Mengakui Pendapatan. Journal of Applied Accounting and Taxation, 1(1), 25-31.

Nurelisa, L. (2016). Hubungan Manajemen Berbasis Kompetensi dengan Kepuasan Kerja Perawat Di RSUD Dr. Wahidin Sudirohusodo (Doctoral dissertation, Universitas Islam Negeri Alauddin Makassar).

Nurhayati, S. (2017). Peranan Manajemen Keuangan Dalam Suatu Perusahaan. Jurnal Bisnis, Manajemen, dan Akuntansi, 4(1), 85-94.

Pujilestari, A., Maidin, A., \& Anggraeni, R. (2016). Budaya Keselamatan Pasien di Instalasi Rawat Inap RSUP DR. Wahidin Sudirohusodo Kota Makassar. Media Kesehatan Masyarakat Indonesia, 10(1), 57-64.

Rani, M., Basalamah, S., \& Damis, H. (2020). Pengaruh Kualitas Pelayanan Terhadap Kepuasan Pasien Rawat Inap di Ruang Perawatan Private Care Center (PCC) RSUP Dr. Wahidin Sudirohusodo Makassar. Tata Kelola, 7(1), 95-114.

Tumbel, K. (2020). Penanganan Medis Pihak Rumah Sakit Kepada Pasien Yang Tidak Mampu Ditinjau Dari Pasal 531 Kuhp Dan Pasal 28a Uud Negara Republik Indonesia Tahun 1945. LEX ET SOCIETATIS, 7(8), 47-54.

Umar, H. (2003), Metode Riset Bisnis, Gramedia Pustaka Utama, Jakarta. 